Open Access

\title{
The Acute Chest Syndrome in Cameroonian children living with sickle cell disease
}

Jobert Richie N. Nansseu ${ }^{1,2^{*}}$, Anastasie Nicole Alima Yanda ${ }^{1}$, David Chelo ${ }^{1,2}$, Sandra A. Tatah ${ }^{1,2}$, Hubert D. Mbassi Awa ${ }^{1,2}$, Judith Seungue ${ }^{1}$ and Paul Olivier N. Koki ${ }^{1,2}$

\begin{abstract}
Background: Although sub-Saharan Africa (SSA) is particularly affected by sickle cell disease (SCD), there is dearth of research on this topic in the region, specifically targeting the magnitude of SCD-related complications. We therefore conducted this study to determine the burden of acute chest syndrome (ACS) and describe its clinical and therapeutic aspects among SCD children in Cameroon, a SSA country.

Methods: This was a retrospective study carried-out from September 2013 to June 2014 at the SCD unit of the Mother and Child Centre of the Chantal Biya Foundation, a pediatric reference centre in Yaoundé, Cameroon. We enrolled all SCD children with confirmed diagnosis of ACS, and recorded their clinical presentation at admission along with their evolution during hospitalization.

Results: Twenty one cases of ACS were identified during the study period, from 338 hospitalizations of children with SCD. Ages ranged from 11 months to 16 years with a mean (standard deviation) of 5.5 (3.4) years, and a male/ female sex ratio of 3.2/1. We noticed relatively low levels of HbF, from 6.4 to $21.9 \%$ with a mean of $14.6 \%$ (6.0 \%). The three main symptoms at admission were fever (90.5\%), cough (81\%) and chest pains (28.6\%). Two patients (9.5\%) developed ACS 2 days after admission. The mean values of leukocytes, neutrophils, serum CRP, serum LDH and hemoglobin were respectively $32479.4(17862.3) / \mathrm{mm}^{3}, 23476(11543.7) / \mathrm{mm}^{3}, 228.2(132.6) \mathrm{mg} / \mathrm{l}, 3452.3(2916.3)$ IU/I and $6.5(1.2) \mathrm{g} / \mathrm{dl}$. The main localizations of radiological alveolar consolidations were the lower lobes (90.5 \%). Treatment associated broad-spectrum antibiotics (100\%), hydration (100 \%), analgesics (43.2\%), whole blood transfusion (66.7\%), and oxygen supplementation (33.3\%). Blood transfusion significantly improved hemoglobin level $(p=0.039)$. The duration of hospitalization, the mean of which was 6.8 (3.1) days, was influenced by none of the tested variables (all $p$ values $>0.05$ ).

Conclusion: ACS is frequent among SCD children in our milieu. Its etiologies seem to be multifactorial. Patients' parents should be educated to recognize early signs and symptoms of the disease, and consult rapidly. Additionally, clinicians must be trained to diagnose ACS, and manage it promptly and efficiently to avoid its related catastrophic consequences.
\end{abstract}

Keywords: Acute chest syndrome, Sickle cell disease, Children, Cameroon, Sub-Saharan Africa

\footnotetext{
* Correspondence: jobertrichie_nansseu@yahoo.fr

${ }^{1}$ Mother and Child Centre of the Chantal Biya Foundation, Yaoundé, Cameroon

${ }^{2}$ Faculty of Medicine and Biomedical Sciences, University of Yaoundé I, PO

Box 1364, Yaoundé, Cameroon
}

\section{Biomed Central}

(C) 2015 Nansseu et al. Open Access This article is distributed under the terms of the Creative Commons Attribution 4.0 International License (http://creativecommons.org/licenses/by/4.0/), which permits unrestricted use, distribution, and reproduction in any medium, provided you give appropriate credit to the original author(s) and the source, provide a link to the Creative Commons license, and indicate if changes were made. The Creative Commons Public Domain Dedication waiver (http://creativecommons.org/publicdomain/zero/1.0/) applies to the data made available in this article, unless otherwise stated. 


\section{Background}

Sickle cell disease (SCD), described for the first time by Herrick in 1910, is an autosomal recessively inherited genetic disorder caused by a single point mutation in the gene encoding the $\beta$-globin chain of hemoglobin $[1,2]$. It is the most widespread and severe monogenetic disorder in the world [3], especially in sub-Saharan Africa (SSA) where it represents a real public health hazard with 1 to $4 \%$ of babies born affected [4]. SCD is associated with multiple acute and chronic complications such as painful vasoocclusive events, cerebral vasculopathy, priapism, chronic kidney disease, acute chest syndrome (ACS) and pulmonary hypertension among others $[5,6]$.

ACS is an acute lung injury syndrome that occurs frequently in patients with SCD. Indeed, it is the second most common cause of hospitalization, and the leading cause of death, contributing to almost $25 \%$ of SCD-related mortality $[7,8]$. Moreover, nearly half of deaths due to ACS occur in SCD patients less than 20 years of age [9]. Repeated episodes of ACS negatively impact long-term lung function, resulting thereby in chronic lung diseases [10].

ACS is currently defined as a new pulmonary infiltrate on chest X-ray consistent with alveolar consolidation but not atelectasis, in conjunction with at least one of the following clinical findings: fever $\left(>38.5{ }^{\circ} \mathrm{C}\right)$, reduced oxygen saturation or $\mathrm{PaO}_{2}(<60 \mathrm{mmHg})$, tachypnea, intercostal retractions, nasal flaring or accessory muscle use, chest pain, cough, wheeze or rales [11, 12]. In 1979, Charache et al. [13] first suggested using the term "acute chest syndrome" for this complication, acknowledging the difficulties in determining its pathogenesis. Till nowadays, the pathophysiology of ACS remains not fully elucidated, yet multiple risk factors have been identified including: male sex, younger age, higher steady-state of leukocyte counts and hemoglobin level, lower hemoglobin $\mathrm{F}(\mathrm{HbF})$ concentrations, previous history of ACS, history of asthma, active smoking or environmental smoke exposure. Furthermore, ACS may be more severe in individuals with HbSS as compared with HbSC disease [6, 7, 14-17].

The etiology of ACS is multifactorial. The three primary studied mechanisms include pneumonia or systemic infection, fat embolism, and direct pulmonary infarction from HbS-containing erythrocytes $[6,11,18]$. The management of this condition is still largely determined by the experience of individual practitioners, and currently there are no conclusive randomized controlled clinical trials to guide therapy [19]. The most common therapy includes nonspecific supportive care strategies aimed at hastening recovery to baseline, including: hospitalization, hydration, analgesics, broad-spectrum antibiotics, bronchodilators, incentive spirometry, supplemental oxygen, and blood transfusions $[6,11,18,19]$.

Although SSA is particularly affected by SCD [4], there is paucity of data on this topic in the region, specifically targeting the magnitude of SCD-related complications. This study was thus undertaken, aiming at determining the burden of ACS and describing its clinical and therapeutic aspects among SCD children in a SSA tertiary pediatric health care facility.

\section{Methods}

\section{Study setting and participants}

This was a retrospective study conducted from September 2013 to June 2014 at the SCD unit of the Mother and Child Centre of the Chantal Biya Foundation. This is a pediatric reference Centre located in Yaoundé, the capital city of Cameroon, a SSA country. This tertiary health care facility receives almost 31,000 consultations with almost 7,000 hospitalizations annually, with patients coming from all over the country. Its SCD unit was opened in December 2008, and is used to dealing with routine out-patient consultations as well as daily follow-up of hospitalized SCD children.

We consecutively and exhaustively included all the patients aged below 18 years and hospitalized in the SCD unit during the study period. These were known SCD children and adolescents with a confirmed diagnosis of ACS (at entry or during hospitalization). The diagnosis of ACS was based on a new radiological alveolar consolidation at the chest X ray, alongside clinical signs and/or symptoms, in keeping with Ballas et al. [12], namely: fever $\left(>38.5{ }^{\circ} \mathrm{C}\right)$, reduced oxygen saturation, tachypnea, intercostal retractions, nasal flaring or accessory muscle use, chest pain, cough, wheeze or rales. Patients who did not perform a chest $\mathrm{X}$ ray or whose chest $\mathrm{X}$ ray did not show any radiological alveolar consolidation were not included in the study. Data were recorded on socio-demographic characteristics, past medical history and events, main complaints and clinical examination at entry, biological and radiological exams (full blood count, thick blood smear, hemocultures, serum CRP (normal $<6 \mathrm{mg} / \mathrm{l}$ ), serum LDH (normal range 313-618 IU/l)) as well as the administered treatment and evolution during hospitalization.

\section{Statistical methods}

Statistical analyses used SPSS, version 20.0 (SPSS Inc, Chicago, Illinois, USA). Results are expressed as mean (Standard Deviation) or count (proportion) as appropriate. Qualitative variable comparisons used the $\chi^{2}$ test or equivalents, and that of quantitative ones, the Student $\boldsymbol{t}$ test for paired samples or non-parametric equivalents. Odds ratios (OR) with $95 \%$ confidence intervals (CI) were used to appreciate the impact of different variables on the duration of hospital stay, and were calculated by logistic regression analyses. A p value $<0.05$ was used to characterize statistically significant results. 


\section{Ethical considerations}

All the procedures used in this survey were in accordance with the current revision of the Helsinki Declaration. This study received approval from the authorities of the Mother and Child Centre of the Chantal Biya Foundation, and was delivered an ethical clearance by the Ethical Review Board of the Faculty of Medicine and Biomedical Sciences, University of Yaoundé I, Cameroon. As the study was retrospective, we could not obtain participants' parents/guardians' consent. Nonetheless, the need for consent was waived by the just-cited institutional review board.

\section{Results}

We recorded on the whole 21 cases of ACS during the study period, on 338 hospitalizations of children with SCD, hence an in-patient prevalence of $6.2 \%$. Table 1 displays the study population's general profile. Ages ranged from 11 months to 16 years, with a mean of 5.5 (3.4) years, and males were more represented than females with

Table 1 General profile of the study population

\begin{tabular}{|c|c|c|}
\hline Characteristic & $\begin{array}{l}\text { Number } \\
(N=21)\end{array}$ & Percentage (\%) \\
\hline \multicolumn{3}{|l|}{ Age groups } \\
\hline $0-5$ years & 11 & 52.4 \\
\hline$>5$ years & 10 & 47.6 \\
\hline \multicolumn{3}{|l|}{ Sex } \\
\hline Male & 16 & 76.2 \\
\hline Female & 5 & 23.8 \\
\hline \multicolumn{3}{|c|}{ Region of origin } \\
\hline Adamawa & 1 & 4.8 \\
\hline Centre & 11 & 52.3 \\
\hline Littoral & 1 & 4.8 \\
\hline North-West & 2 & 9.5 \\
\hline South & 3 & 14.3 \\
\hline West & 3 & 14.3 \\
\hline \multicolumn{3}{|c|}{ Regularly followed-up } \\
\hline No & 13 & 61.9 \\
\hline Yes & 9 & 38.1 \\
\hline \multicolumn{3}{|c|}{ Adequately vaccinated for the age } \\
\hline No & 14 & 66.7 \\
\hline Yes & 7 & 33.3 \\
\hline \multicolumn{3}{|c|}{ Currently taking folic acid } \\
\hline No & 12 & 52.1 \\
\hline Yes & 9 & 47.9 \\
\hline \multicolumn{3}{|c|}{$\begin{array}{l}\text { Currently taking antibiotic prophylaxis } \\
\text { For the } 0-5 \text { years old }(N=11)\end{array}$} \\
\hline No & 8 & 72.7 \\
\hline Yes & 3 & 27.3 \\
\hline
\end{tabular}

a sex ratio of 3.2/1 (Tables 1 and 2). Only seven patients had a hemoglobin electrophoresis dating back to less than one year, $\mathrm{HbS}$ ranging from $55 \%$ to $86 \%$ with a mean of 75.1 (11.9) \%, and $\mathrm{HbF}$, from $6.4 \%$ to $21.9 \%$ with a mean of 14.6 (6.0) \% (Table 2). Only $38.1 \%$ of children were regularly followed-up, i.e. were used to visiting the unit for a check-up at least every 3 months. Besides, not more than $33.3 \%$ of our patients had been adequately vaccinated in accordance with their ages, and only 3 children aged $0-5$ years $(27.3 \%)$ were currently taking an antibiotic prophylaxis (Table 1 ).

According to our patients' parents, duration of evolution of symptoms before consultation ranged from less than $24 \mathrm{~h}$ to almost 14 days, with a mean of 4.8 (4.2) days. The presenting complaints are reported in Table 3. The three main symptoms were fever $(90.5 \%)$, cough $(81 \%)$, and chest pains $(28.6 \%)$. The main clinical signs we observed were pulmonary consolidation (100\%), an altered general appearance (61.9\%), clinical signs of anemia (57.1\%), a systemic inflammatory response syndrome (57.1\%), and signs of respiratory distress (33.3\%). Two patients (9.5\%) who were initially admitted for vaso-occlusive crises (VOC) developed ACS after 2 days of hospitalization. Results of biological tests showed very high levels of leukocytes, neutrophils, serum CRP and serum LDH. Indeed, their mean values were $32479.4(17862.3) / \mathrm{mm}^{3}$, $23476(11543.7) / \mathrm{mm}^{3}, 228.2$ (132.6) $\mathrm{mg} / \mathrm{l}$, and 3452.3 (2916.3) IU/l respectively. Contrariwise, we observed relatively low levels of hemoglobin, with a mean of 6.5 (1.2) $\mathrm{g} / \mathrm{dl}$ (Table 2). The main localizations of radiological alveolar consolidations were the lower lobes $(90.5 \%)$. None of the 10 hemocultures performed was positive, and only one of the 15 thick blood smears performed to seek for malaria parasites was positive to Plasmodium species, specifically Plasmodium falciparum (6.7 \%; Table 3).

Patients were placed on two to three antibiotics: a betalactam (either ampicillin or ceftriaxone) + a macrolide (oral azithromycin) \pm an aminoglycoside (gentamicin) (Table 4). Two days after the fever had dropped, patients were switched to oral cephalosporin (cefixim) or amoxicillin accordingly, for a total duration of 10 to 14 days (both intravenously and orally). Two patients $(9.5 \%)$ initially placed on ceftriaxone were still presenting fever on the fourth day of antibiotherapy; they were subsequently switched to vancomycin for seven days with a good improvement. Adjuvant therapy included hyperhydration (100\%), paracetamol (100 \%) for fever or pains, tramadol (42.9 \%) and ibuprofen (23.8 \%). Fourteen patients (66.7\%) were transfused with whole blood, and all of them concurrently received an anti-malarial treatment to prevent transfusion-transmitted malaria. All the seven patients $(33.3 \%)$ who presented signs of respiratory distress were placed on oxygen, its duration ranging from 1 to 5 days with a mean of 3.6 (1.6) days (Tables 2, 3 and 4). 
Table 2 Summary of quantitative variables

\begin{tabular}{|c|c|c|c|c|c|c|}
\hline Variable & Min & Max & Mean & SD & Median & IQR \\
\hline Age (years) $N=21$ & 0.92 & 16 & 5.5 & 3.4 & 5.0 & $3.4-7$ \\
\hline $\mathrm{HbS}(\%) N=7$ & 55 & 86 & 75.1 & 11.9 & 77.9 & $66-86$ \\
\hline $\mathrm{HbF}(\%) N=7$ & 6.4 & 21.9 & 14.6 & 6.0 & 14.8 & $9.7-19.7$ \\
\hline Leukocytes $\left(/ \mathrm{mm}^{3}\right) \quad N=18$ & 10600 & 73900 & 32479.4 & 17862.3 & 30295 & 19050-37875 \\
\hline Neutrophils $\left(/ \mathrm{mm}^{3}\right) \quad N=18$ & 4800 & 51600 & 23476 & 11543.7 & 24100 & $11600-28100$ \\
\hline Hemoglobinemia $(\mathrm{g} / \mathrm{dl}) \quad N=18$ & 4.9 & 8.4 & 6.48 & 1.15 & 6.25 & $5.4-7.6$ \\
\hline Serum LDH (UI/I) N= 11 & 1307 & 10366 & 3452.3 & 2916.3 & 2093 & $1623-5301$ \\
\hline Serum CRP $(\mathrm{mg} / \mathrm{l}) \mathrm{N}=14$ & 4.5 & 432 & 228.2 & 132.6 & 233.5 & $89-326$ \\
\hline Leukocytes $^{\mathrm{a}}\left(/ \mathrm{mm}^{3}\right) N=7$ & 8300 & 39100 & 21557.2 & 11843.3 & 18900 & $11000-35200$ \\
\hline Neutrophils ${ }^{\mathrm{a}}\left(/ \mathrm{mm}^{3}\right) \mathrm{N}=7$ & 5800 & 29716 & 16319.3 & 10892.7 & 13400 & $6475-29100$ \\
\hline Hemoglobinemia $(\mathrm{g} / \mathrm{dl}) \quad N=7$ & 7.5 & 13.9 & 9.6 & 2.3 & 9.4 & $7.5-10.6$ \\
\hline Duration of oxygen therapy (days) $N=7$ & 1 & 5 & 3.6 & 1.6 & 4 & $2-5$ \\
\hline Duration of hospitalization (days) $N=21$ & 3 & 12 & 6.8 & 3.1 & 6 & $5-9.5$ \\
\hline
\end{tabular}

${ }^{\mathrm{a}}$ control values

A control full blood count was performed only by seven of our patients $48 \mathrm{~h}$ after blood transfusion (Table 3). We did not find any statistical difference between the first and second leukocyte counts $(p=0.711)$, this being the same for neutrophil counts $(p=0.811)$. By contrast, we did notice a significant increase in hemoglobinemia $(p=0.039)$. The duration of hospitalization ranged from 3 to 12 days with a mean of 6.8 (3.1) days. One patient of the female sex died on the fourth day of hospitalization, hence a mortality rate of $4.8 \%$ (Tables 2 and 4). While investigating factors that could have impacted the duration of hospitalization, we found that age, sex, regular follow-up, immunization status, duration of evolution of symptoms prior to consultation, transfusion, oxygen, and the antibiotic used were not implicated in the determination of duration of hospitalization (all p values $>0.05$ as depicted by Table 5).

\section{Discussion}

This study showed that ACS accounted for $6.2 \%$ of SCD children hospital admissions with almost 2.1 SCD patients presenting ACS per month. This proportion is comparable to the 1.9 ACS episodes/month among hospitalized SCD children in Bruxelles [15], and higher than the 1.4, 0.3 and 0.2 ACS episodes/month respectively reported in Brazzaville, Antananarivo and French Guiana [20-22]. However, our prevalence of ACS is lower than the $10-20 \%$ rate of hospital admissions reported by Miller and Gladwin in their review [6]. Our prevalence may be an underestimate of the real burden of ACS among our children suffering from SCD for some reasons. First, hemoglobin electrophoresis is not systematically performed in our milieu, and many parents neither know their status nor that of their kids. As we considered only known SCD patients, some unknown SCD patients may have presented this condition and escaped from enrolment. Second, due to parents' financial constraints, we are used to performing just one chest $\mathrm{x}$-ray during hospitalization. As a result, we could have missed all those whose first chest $\mathrm{x}$-ray was normal but who developed ACS later on, given that radiographic findings in case of ACS may progress over time $[9,11,23]$. If it is true that a positive chest $\mathrm{x}$-ray is the key element to define the disease [12], there have been some claims that a single negative chest $\mathrm{x}$-ray cannot exclude the disease [23-25], taking into account that clinical assessment may appear inadequate to identify ACS [11]. It has been also suggested that every SCD patient presenting with fever must undergo a chest $\mathrm{x}$-ray $[11,24]$.

Consequently, close clinical monitoring alongside serial radiographic evaluation (without ignoring the risk of radiation) is necessary. In fact, it has been shown that ACS may develop 1 to 3 days after admission for VOC as there may exist a close relationship between ACS and VOC $[6,11,15,24]$. This is truer for adults than children, as the latter usually present with ACS at admission [26]. In our study for instance, only 2 children (9.5\%) developed ACS 2 days after admission, and pains were concomitantly associated in $52.4 \%$ of cases. Some risk factors involved in the development of ACS during hospital stay have been identified such as the male sex, past medical history of ACS, thoracic pains at entry and use of morphine during hospitalization [15, 27].

Although we did not assess risk factors of developing ACS, we observed a male predominance and relatively low levels of HbF, in line with the literature $[6,16,17]$. We also found that fever $(90.5 \%)$, cough $(81 \%)$ and thoracic pains $(28.6 \%)$ were the main symptoms in keeping with previous reports $[9,21,28]$, these symptoms being mainly in favor of pulmonary infections. Despite the fact that we 
Table 3 Clinical features of ACS

\begin{tabular}{|c|c|c|}
\hline & $\begin{array}{l}\text { Number } \\
(N=21)\end{array}$ & $\begin{array}{l}\text { Percentage } \\
(\%)\end{array}$ \\
\hline \multicolumn{3}{|l|}{$\begin{array}{l}\text { Duration of evolution of symptoms before } \\
\text { consultation }\end{array}$} \\
\hline$\leq 48 \mathrm{~h}$ & 6 & 28.6 \\
\hline$>48 \mathrm{~h}$ & 15 & 71.4 \\
\hline \multicolumn{3}{|l|}{ Symptoms motivating consultation } \\
\hline Fever & 19 & 90.5 \\
\hline Cough & 17 & 81 \\
\hline Thoracic pains & 6 & 28.6 \\
\hline Generalized pains & 6 & 28.6 \\
\hline Abdominal pains & 5 & 23.8 \\
\hline Dyspnea & 5 & 23.8 \\
\hline Asthenia & 2 & 9.5 \\
\hline Referred for management of severe anemia & 3 & 14.3 \\
\hline Priapism & 1 & 4.8 \\
\hline Vomiting & 1 & 4.8 \\
\hline \multicolumn{3}{|l|}{ Clinical signs } \\
\hline Altered general appearance & 13 & 61.9 \\
\hline Pulmonary consolidation & 21 & 100 \\
\hline Clinical anemia & 12 & 57.1 \\
\hline Respiratory distress & 7 & 33.3 \\
\hline Systemic inflammatory response syndrome & 12 & 57.1 \\
\hline Jaundice & 2 & 9.5 \\
\hline Hemoglobinuria & 1 & 4.8 \\
\hline \multicolumn{3}{|l|}{ Result of the chest $X$ ray } \\
\hline Right upper lobe consolidation & 2 & 9.5 \\
\hline $\begin{array}{l}\text { Right middle and lower lobes } \\
\text { consolidation }\end{array}$ & 2 & 9.5 \\
\hline Right lower lobe consolidation & 12 & 57.1 \\
\hline Left lower lobe consolidation & 3 & 14.3 \\
\hline Right and left lower lobes consolidation & 2 & 9.5 \\
\hline \multicolumn{3}{|l|}{ Hemocultures } \\
\hline Not done & 11 & 52.4 \\
\hline Negative & 10 & 47.6 \\
\hline Positive & 0 & 0 \\
\hline \multicolumn{3}{|l|}{ Malaria parasitemia (by thick blood smear) } \\
\hline Not done & 6 & 28.6 \\
\hline Negative & 14 & 66.7 \\
\hline Positive & 1 & 4.8 \\
\hline
\end{tabular}

did not have our patients' baseline leukocyte counts (explained by the fact that many of our patients are not regularly followed-up and are from financially-limited families), we noticed very high leukocyte counts [32479 (17862) $\mathrm{mm}^{3}$ ], especially neutrophils [23476 (11543) $\left.\mathrm{mm}^{3}\right]$, associated with elevated serum CRP levels [228.2
Table 4 Management and outcome

\begin{tabular}{|c|c|c|}
\hline & Number $(N=21)$ & Percentage (\%) \\
\hline \multicolumn{3}{|l|}{ Antibiotherapy } \\
\hline \multicolumn{3}{|l|}{ Beta-lactam } \\
\hline Ceftriaxone (IV: 50 mg/kg/day) & 10 & 47.6 \\
\hline Ampicillin (IV: 50 mg/kg/8 h) & 11 & 52.4 \\
\hline Gentamicin (IV: 3 mg/kg/day) & 16 & 76.2 \\
\hline Azithromycin (oral: 5-10 mg/kg/day) & 21 & 100 \\
\hline \multicolumn{3}{|l|}{ Adjuvant therapy } \\
\hline Tramadol (IV: 1-2 mg/kg/6 h) & 9 & 42.9 \\
\hline $\begin{array}{l}\text { Paracetamol (oral or IV: } \\
15 \mathrm{mg} / \mathrm{kg} / 6 \mathrm{~h} \text { ) }\end{array}$ & 21 & 100 \\
\hline Ibuprofen (oral: 10 mg/kg/8 h) & 5 & 23.8 \\
\hline Hyperhydration $\left(2.5-3 \mathrm{l} / \mathrm{m}^{2} \mathrm{BS}^{\mathrm{a}}\right)$ & 21 & 100 \\
\hline \multicolumn{3}{|l|}{ Anti-malarial treatment } \\
\hline No & 7 & 33.3 \\
\hline Yes & 14 & 66.7 \\
\hline \multicolumn{3}{|l|}{ Oxygen therapy } \\
\hline No & 14 & 66.7 \\
\hline Yes & 7 & 33.3 \\
\hline \multicolumn{3}{|l|}{ Transfusion } \\
\hline No & 7 & 33.3 \\
\hline Yes & 14 & 66.7 \\
\hline \multicolumn{3}{|l|}{ Death } \\
\hline Yes & 1 & 4.8 \\
\hline No & 20 & 95.2 \\
\hline \multicolumn{3}{|l|}{ Duration of hospitalization } \\
\hline$\leq 5$ days & 8 & 38.1 \\
\hline$>5$ days & 13 & 61.9 \\
\hline
\end{tabular}

${ }_{\mathrm{a} S}=$ Body surface; IV = intravenous

(132.6]. These elements are also strongly suggestive that infection may initiate or precipitate the development of ACS among our patients, corroborating previous reports elsewhere $[15,16]$. However, though blood culture was not performed in all patients, no germ was identified. This result was also reported by Rucknagel et al. [25] who incriminated rib infarction as the main etiology of ACS. But without invasive procedures (bronchoscopy with bronchoalveolar lavage), it is very difficult to rule out conclusively a bacterial infection as a cause of ACS. Microorganisms that have been identified associated with ACS include Streptococcus pneumonia, Chlamydiae pneumonia, Mycoplasma pneumonia, influenza virus A H1N1, parainfluenza virus, respiratory syncytial virus and coronavirus among others $[15,21,23]$.

Besides, we observed that radiological abnormalities of the lower lobes $(90.5 \%)$ were the prevailing ones, mirroring previous findings $[23,28]$. Contrariwise, other studies 
Table 5 Factors influencing the duration of hospitalization (equal or below 5 days)

\begin{tabular}{|c|c|c|c|}
\hline Variable & Odds ratio & $95 \%$ Confidence interval & $p$ value \\
\hline \multicolumn{4}{|l|}{ Age } \\
\hline $0-5$ years & 0.375 & $0.061-2.305$ & 0.268 \\
\hline$>5$ years & 1 & & \\
\hline \multicolumn{4}{|l|}{ Sex } \\
\hline Male & 1 & & \\
\hline Female & 3.3 & $0.413-26.366$ & 0.262 \\
\hline \multicolumn{4}{|l|}{ Regularly followed-up } \\
\hline No & 1.042 & $0.169-6.402$ & 0.664 \\
\hline Yes & 1 & & \\
\hline \multicolumn{4}{|l|}{ Immunization status } \\
\hline Not good for age & 0.300 & $0.045-1.993$ & 0.213 \\
\hline Good for age & 1 & & \\
\hline \multicolumn{4}{|c|}{ Duration of symptoms } \\
\hline$\leq 48 \mathrm{~h}$ & 5.5 & $0.710-42.600$ & 0.115 \\
\hline$>48 \mathrm{~h}$ & 1 & & \\
\hline \multicolumn{4}{|l|}{ Transfusion } \\
\hline No & 2.0 & $0.291-13.738$ & 0.410 \\
\hline Yes & 1 & & \\
\hline \multicolumn{4}{|l|}{ Oxygen therapy } \\
\hline No & 6 & $0.565-63.676$ & 0.113 \\
\hline Yes & 1 & & \\
\hline \multicolumn{4}{|l|}{ Antibiotic used } \\
\hline Ceftriaxone & 1 & & \\
\hline Ampicillin & 1.944 & $0.322-11.756$ & 0.392 \\
\hline
\end{tabular}

showed that the main radiological localizations of ACS were the upper lobes in children, and the lower ones in adults [9, 20]. While the upper lobes predominance has been associated with an infectious etiology especially in children, the lower or multi-lobes predominance has been linked to pulmonary thrombosis and fat embolism $[9,16,20]$ or rib infarction [25]. Our results are therefore suggestive that the pathogenesis of ACS in our setting is also multifactorial. Further well-designed studies with large sample sizes are warranted to better elucidate the etiology of ACS in our setting.

In line with the literature $[6,19,22]$, our management of ACS included broad-spectrum antibiotherapy, hydration, analgesics, supplemental oxygen and transfusion, but none of these supportive care impacted the duration of hospital stay. Actually, only patients presenting respiratory distress were placed on oxygen, mainly due to limitation of resources. Likewise, we transfused only SCD patients who had a hemoglobin level $\leq 7 \mathrm{~g} / \mathrm{dl}$ given that blood safety remains an issue of major concern in the milieu [29]. Although transfusion did not reduce the hospital stay, it significantly increased the hemoglobin level $(p=0.039)$, perhaps improving therefore the clinical state of our patients. Early transfusion of SCD patients presenting with ACS should be encouraged in SSA settings, especially transfusion of packed red blood cells instead of whole blood to reduce transfusion-related adverse reactions, despite recurrent blood shortages that occur in the region [30]. Nonetheless, more studies are needed to underpin this suggestion with robust scientific evidence and indicate which threshold should be considered to transfuse SCD children suffering from ACS.

The mean duration of hospitalization we found ( 6.8 days) is comparable to the 7 days-duration reported by Bertholdt et al. [15], but a bit higher than findings from Vichinsky et al. (5.4 days) [9] and lower than what has been reported by Vichinsky et al. in another study [23] and Hunald et al. [21]: more than 10 days and 12 days respectively. Introduction of other supportive care in our practice like bronchodilators and incentive spirometry as elsewhere $[6,19]$, along with systematic oxygen supplementation and early blood transfusion could substantially reduce the duration of hospital stay. Furthermore, the use of dexamethasone deserves some close considerations. In fact, there is body of evidence bolstering that low dose dexamethasone $(0.3 \mathrm{mg} / \mathrm{kg} / 12 \times 4$ doses $)$ significantly diminished the duration of hospital stay, the need for blood transfusion, oxygen and analgesics use, and duration of fever, without a rebound effect [31] which was observed with high dose methylprednisolone in cases of VOC [32].

One of our patients died, hence a mortality rate of $4.8 \%$ which concurs the $4 \%$ percentage obtained by Bertholdt et al. in Belgium [15]. This was an inadequatelyvaccinated and unregularly-followed female SCD patient aged 18 months, with a $\mathrm{HbF}$ level of $18.9 \%$. She was brought to consult for fever, cough and respiratory distress, and the chest $\mathrm{x}$-ray revealed medium and lower right lobes alveolar consolidations. Titers of LDH and CRP were respectively $10366 \mathrm{IU} / \mathrm{l}$ and $414 \mathrm{mg} / \mathrm{l}$. She was placed on a triple antibiotherapy (ceftriaxone, gentamycin and azithromycin), oxygen supplementation, and was transfused as well. But she died at day 4 of hospitalization in a context of severe sepsis.

Unfortunately, the retrospective design and small sample size constitute some weaknesses of the present study. Besides, generalization of our results may be impeded by the use of data collected from only one hospital centre. Another limitation is that biological data were incomplete due to parents' financial limitations, as the study was not sponsored. Nonetheless, in this particularly difficult context, we carried-out serious and reliable data collection and analyses, and have shown that despite the difficulties in managing our patients, the outcome is relatively similar when compared with resource-rich settings in terms of duration of hospital stay and mortality rate. Eventually, 
and to the best of our knowledge, this is the first study conducted in our milieu targeting ACS burden and presentations.

\section{Conclusion}

ACS is frequent among SCD children in our milieu. Its etiologies seem to be multifactorial including infection, pulmonary thrombosis and fat embolism. After an initial normal chest $\mathrm{x}$-ray, especially in a patient presenting with VOC, repeated clinical evaluation must be conducted and possible changes in the clinical status should indicate the necessity of a new radiographic examination. Patients' parents should be educated to recognize early signs and symptoms of the disease, and consult rapidly. Additionally, clinicians must be trained to correctly diagnose ACS, and manage it promptly and efficiently to avoid its related catastrophic consequences. Additive treatment such as incentive spirometry, bronchodilators and even low dose dexamethasone could perhaps be introduced in our settings to reduce the hospital stay and hasten recovery. On recovery, treatment with hydroxyurea should be discussed to reduce the likelihood of recurrent episodes.

\section{Abbreviations}

ACS: Acute chest syndrome; Hb: Hemoglobin; SCD: Sickle cell disease; SSA: Sub-Saharan Africa; VOC: Vaso-occlusive crisis.

\section{Competing interests}

The authors declare that they have no competing interests.

\section{Authors' contributions}

JRNN conceived and designed the study, collected and analyzed the data, and drafted the manuscript. ANAY participated in study conception and design, in data collection, and in critical revision of the manuscript. DC, SAT, HDMA, JS and PONK participated in critical revision of the manuscript. All authors read and approved the final manuscript.

\section{Acknowledgments}

The authors gratefully acknowledge the medical staff of the SCD unit of the Mother and Child Centre, as well as all the nurses, especially Mrs. Essomba Evarine and Tanjon Rita for their constant devotion to care for these vulnerable SCD children. They also want to thank Chavely Gwladys Monamele who helped them to revise the manuscript.

Received: 12 December 2014 Accepted: 14 September 2015 Published online: 21 September 2015

\section{References}

1. Kato GJ, Gladwin MT, Steinberg MH. Deconstructing sickle cell disease: reappraisal of the role of hemolysis in the development of clinical subphenotypes. Blood Rev. 2007;21:37-47.

2. Rees DC, Williams TN, Gladwin MT. Sickle-cell disease. Lancet. 2010;376:2018-31.

3. Weatherall D, Hofman K, Rodgers G, Ruffin J, Hrynkow S. A case for developing North-south partnerships for research in sickle cell disease. Blood. 2005;105:921-3.

4. Aliyu ZY, Gordeuk V, Sachdev V, Babadoko A, Mamman Al, Akpanpe P, et al. Prevalence and risk factors for pulmonary artery systolic hypertension among sickle cell disease patients in Nigeria. Am J Hematol. 2008;83:485-90.

5. Panepinto JA, O'Mahar KM, DeBaun MR, Loberiza FR, Scott JP. Health-related quality of life in children with sickle cell disease: Child and parent perception. Br J Haematol. 2005;130(3):437-44.
6. Miller AC, Gladwin MT. Pulmonary complications of sickle cell disease. Am J Respir Crit Care Med. 2012;185(11):1154-65.

7. Platt OS, Brambilla DJ, Rosse WF, Milner PF, Castro O, Steinberg MH, et al. Mortality in sickle cell disease. Life expectancy and risk factors for early death. N Engl J Med. 1994;330(23):1639-44.

8. Fauroux B. Respiratory distress and drepanocytosis].[Article in French. Arch Pediatr. 2000;7:82-6.

9. Vichinsky EP, Styles LA, Colangelo LH, Wright EC, Castro O, Nickerson B. Acute chest syndrome in sickle cell disease: clinical presentation and course. Cooperative study of sickle cell disease. Blood. 1997;89(5):1787-92.

10. Sylvester KP, Patey RA, Milligan P, Rafferty GF, Broughton $S$, Rees D, et al. Impact of acute chest syndrome on lung function of children with sickle cell disease. J Pediatr. 2006;149(1):17-22.

11. Bernard AW, Yasin Z, Venkat A. Acute chest syndrome of sickle cell disease. Hospital Physician. 2007;44:5-23.

12. Ballas SK, Lieff S, Benjamin LJ, Dampier CD, Heeney MM, Hoppe C, et al. Definitions of the phenotypic manifestations of sickle cell disease. Am J Hematol. 2010;85(1):6-13.

13. Charache S, Scott JC, Charache P. "Acute chest syndrome" in adults with sickle cell anemia. Arch Intern Med. 1979;139:67.

14. Knight-Madden JM, Forrester TS, Lewis NA, Greenough A. Asthma in children with sickle cell disease and its association with acute chest syndrome. Thorax. 2005;60(3):206-10.

15. Bertholdt S, Lê PQ, Heijmans C, Huybrechts S, Dedeken L, Devalck C, et al. Respiratory complications of sickle cell anemia in children: the acute chest syndrome]. [Article in French. Rev Med Brux. 2012;33(3):138-44.

16. Castro O, Brambilla DJ, Thorington B, Reindorf CA, Scott RB, Gillette $P$, et al. The acute chest syndrome in sickle cell disease: incidence and risk factors. The Cooperative Study of Sickle Cell Disease. Blood. 1994;84(2):643-9.

17. Lamarre $Y$, Romana $M$, Waltz $X$, Lalanne-Mistrih $M L$, Tressières $B$, DivialleDoumdo $L$, et al. Hemorheological risk factors of acute chest syndrome and painful vaso-occlusive crisis in children with sickle cell disease. Haematologica. 2012;97(11):1641-7.

18. Gladwin MT, Vichinsky E. Pulmonary complications of sickle cell disease. N Engl J Med. 2008;359(21):2254-65

19. Miller ST. How I treat acute chest syndrome in children with sickle cell disease. Blood. 2011;117(20):5297-305.

20. Babela JR, Nzingoula S, Senga P. Sickle-cell crisis in the child and teenager in Brazzaville, Congo. A retrospective study of 587 cases]. [Article in French. Bull Soc Pathol Exot. 2005;98(5):365-70.

21. Hunald FA, Rakotoarisoa AJC, Rajaobelison T, Rajaonarivony MFV, Rakotovao HJL, Rakoto-Ratsimba HN, et al. Acute thoracic syndrome in child sickle-cell disease]. [Article in French. Rev Trop Chir. 2010;4:41-3.

22. Elenga N, Cuadro E, Martin E, Cohen-Addad N, Basset T. Associated factors of acute chest syndrome in children with sickle cell disease in French Guiana. Int J Pediatr. 2014;2014:213681.

23. Vichinsky EP, Neumayr LD, Earles AN, Williams R, Lennette ET, Dean D, et al. Causes and outcomes of the acute chest syndrome in sickle cell disease. National acute chest syndrome study group. N Engl J Med. 2000;342(25):1855-65.

24. Neocleous C, Spanou C, Adramerina A, Spyrou G, Tzanetis F. Painful vasoocclusive crisis as a prodromal phase of acute chest syndrome. Is only one chest X-ray enough? A case report. Prague Med Rep. 2013;114(3):180-5.

25. Rucknagel DL. The role of rib infarcts in the acute chest syndrome of sickle cell diseases. Pediatr Pathol Mol Med. 2001;20(2):137-54.

26. Habibi A, Bachir D, Godeau B. Complications aiguës de la drépanocytose. Rev Prat. 2004;54:1548-54.

27. Birken CS, Khambalia A, Dupuis A, Pastor A, Lee M, Padavattan K, et al. Morphine is associated with acute chest syndrome in children hospitalized with sickle cell disease. Hosp Pediatr. 2013;3(2):149-55.

28. Sprinkle RH, Cole T, Smith S, Buchanan GR. Acute chest syndrome in children with sickle cell disease. A retrospective analysis of 100 hospitalized cases. Am J Pediatr Hematol Oncol. 1996;8(2):105-10.

29. Noubiap JJ, Joko WY, Nansseu JR, Tene UG, Siaka C. Sero-epidemiology of human immunodeficiency virus, hepatitis $B$ and $C$ viruses, and syphilis infections among first-time blood donors in Edéa, Cameroon. Int J Infect Dis. 2013;17(10):e832-7.

30. Nansseu JR, Noubiap JJ, Ndoula ST, Zeh AF, Monamele CG. What is the best strategy for the prevention of transfusion-transmitted malaria in sub-Saharan African countries where malaria is endemic? Malar J. 2013;12:465. 
31. Bernini JC, Rogers ZR, Sandler ES, Reisch JS, Quinn CT, Buchanan GR. Beneficial effect of intravenous dexamethasone in children with mild to moderately severe acute chest syndrome complicating sickle cell disease. Blood. 1998;92(9):3082-9.

32. Griffin TC, Mclntire D, Buchanan GR. High-dose intravenous methylprednisolone therapy for pain in children and adolescents with sickle cell disease. N Engl J Med. 1994;330(11):733-7.

Submit your next manuscript to BioMed Central and take full advantage of:

- Convenient online submission

- Thorough peer review

- No space constraints or color figure charges

- Immediate publication on acceptance

- Inclusion in PubMed, CAS, Scopus and Google Scholar

- Research which is freely available for redistribution 